\title{
Low-Stress and Efficient Design of Integrated Boost Series Parallel Fly-Back Converters
}

\author{
Sravan Kumar Soma ${ }^{1 *}$, Ravi Sankara Reddy Netapally², Vijay Kumar Mallapu ${ }^{1}$ \\ ${ }^{1}$ Department of EEE, JNTUA College of Engineering, Ananthapuram, AP-515001, India \\ ${ }^{2}$ Department of EEE, G. Pulla Reddy Engineering College, Kurnool, AP-518346, India
}

Corresponding Author Email: sravan_257@gnits.ac.in

https://doi.org/10.18280/jesa.530310

Received: 7 April 2020

Accepted: 20 May 2020

\section{Keywords:}

Integrated Boost Series Parallel Fly-Back

Converter (IBSPFC), QSC (Quasi Switched

Capacitor), voltage mode control

\begin{abstract}
This paper Presents comparative analysis of IBSPFC \&QSC Based IBSPFC by using FPGA. By using this IBSPFC the voltage stress is reduced across the switch when compare to conventional fly-back converters. The multi winding transformer gives higher reliability i.e. if any one of the winding damages other one supplies power to the load. On the other hand, QSC based IBSPFC will achieved Zero voltage \& Zero current switching, which will increase more efficiency when compare to conventional single stage integrated converters and IBSPFC. Operating modes of QSC, based IBSPFC\&IBSPFC have been introduced. The primary side winding of the fly-back transformer is coupled in series across with bulk capacitor to minimize switch voltage stress and the secondary winding of the 1:1 fly-back transformer. Basic voltage mode control Techniques are used to control the output voltage and current. An input voltage of $25 \mathrm{~V}$ primary side and $50 \mathrm{~V}$ battery at secondary side, 100v output, $100 \mathrm{~W}$ and $100 \mathrm{KHz}$ DC-Dc isolated QSC based IBSPFC is implemented using FPGA SPARTAN6LX9 and experimental results and comparative table have been presented.
\end{abstract}

\section{INTRODUCTION}

Existent Solar Power creation has addition leads in finding and running price different to more energy sources. Solar power is a clean method with nil least preservation. Mainly PV cells can be built on the topmost of apartments or homes and trade in metropolitan cities. In solar power, there is chance of irradiation fluctuation, which makes use of battery storage system to provide the required power to load [1]. Due to separate sources, an individual power electronic converter is required which increase the complexity of the circuit shown in Figure 1 (a). To reduce the cost and complexity of the circuit a multi input dc-dc converter is preferred [2] which are shown in Figure 1(b). Presently dual input topologies are classified into two ways. One is non-isolated another one is isolated [214]. The basic non-isolated topologies of dc-dc converters are again classified as Buck, Boost and Buck-boost converters suffering from isolation and at the load side it requires large AC Transformers [3, 4]. Otherwise, the utility grid may affect leakage current in between solar panels and earth. The isolated converters of dual input $\mathrm{dc} / \mathrm{dc}$ help to avoiding the line frequency transformer $[5,6]$. The basic isolated $\mathrm{dc} / \mathrm{dc}$ converters are fly back, half bridge, forward, push pull and full bridge converters [7-9]. To transfer the power from multiple sources to the output a separate isolated transformer is required for each source and the number of switches are increased followed by cost [10-15]. To eliminate this problem a two winding transformer is used [16-24]. By losing the isolation between the energy sources of single side of the isolation transformer the total number of switches in this type of topologies are reduced and Battery is connected at secondary side of the isolation transformer, the battery does not require any isolation to the output of the load [25-32].
Therefore, this type of topology is better than using multiple transformers. As the application in this paper is $100 \mathrm{w}$ or $200 \mathrm{w}$, hence fly back converter is chosen. The basic fly back converter requires two snubber circuits one is at primary winding of transformer another one is at switch, which is connected in series with the transformer.

Generally, the fly back converter duty cycle is limited to 0.5 .

To eliminate these problems IBSPFC and QSC based IBSPFC is preferred for $100 \mathrm{w}$ or $200 \mathrm{w}$ applications. In this paper single switch IBSPFC and QSC based IBSPFC is introduced. The main advantage of QSC based IBSPFC is it will reduce voltage stress on the switches, high reliability and ZVS and ZCS will achieve hence efficiency of the converter is improved [32].

The research study along with experimental results of IBSPFC with QSC is presented in this paper for closed loop control. The design considerations for inductor in boost circuit, quasi switched capacitor and output capacitor are evaluated. This presents design of QSC based IBSPFC operating at 100 $\mathrm{kHz}$ with DC input voltage magnitude of $25 \mathrm{~V}$ on primary side, producing $50 \mathrm{~V}$ and $100 \mathrm{~V}$ at secondary side and at load with $100 \mathrm{~W}$ of output power. The operating modes of IBSPFC are presented in Section 2 Present Necessity of IBSPFC and QSC based IBSPFC. Section 3. Section 4 presents mathematical Analysis; experimental results of the proposed circuit are shown in Section 5 for closed loop, Section 6 Working Methods of QSC Based IBSPFC. Section 7 Mathematical Calculations of QSC based IBSPFC. Section 8 Experimental Results of QSC based IBSPFC. Section 9 conclusion. and References related to the performance of the proposed circuit is discussed in this above Sections. 


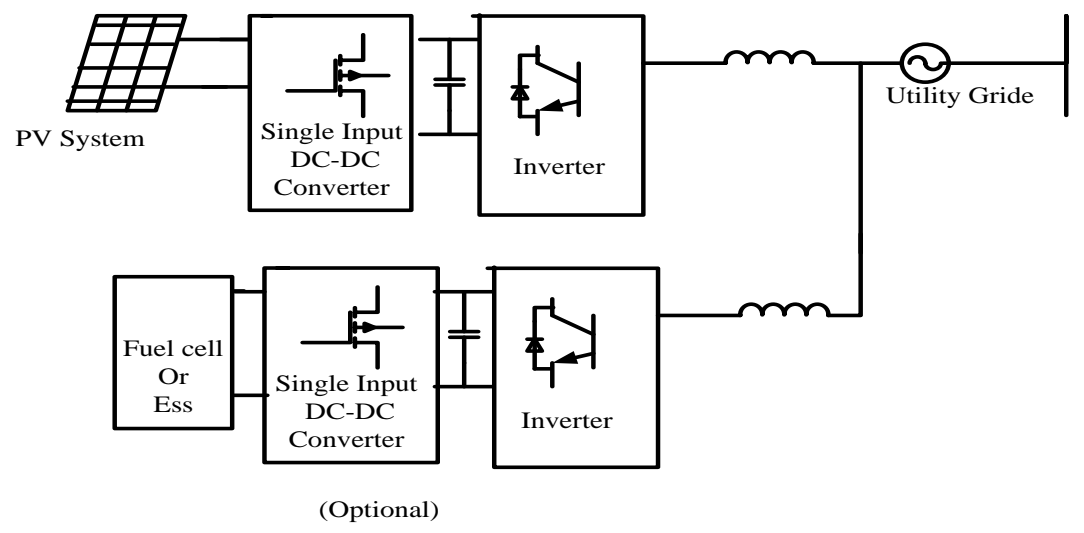

(a). Present formation

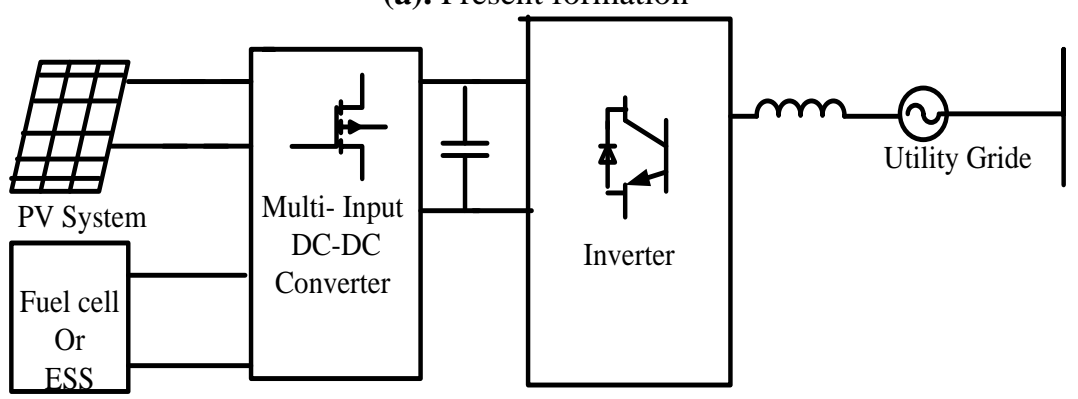

(b). System formation with a multiple-input dc/dc converter

Figure 1. Different system configurations with both PV and Fuel cell or ESS

\section{NECESSITY OF IBSPFC AND QSC BASED IBSPFC}

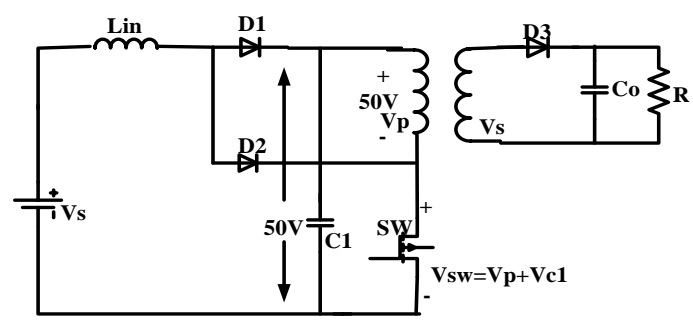

(a). IBFC

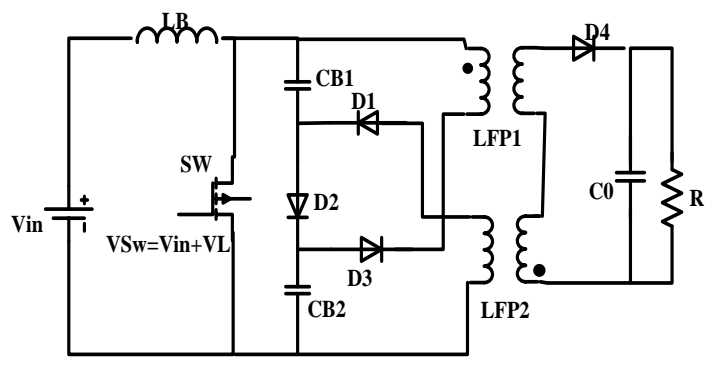

(b). IBSPFC

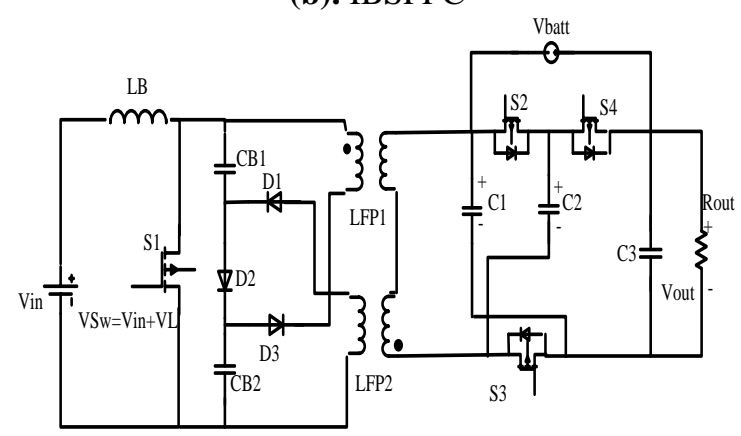

(c). IBSPFC with QSC based Dual Input Converter

Figure 2. Different topologies Boost Fly-back converter
Figure 2 Shows the different topologies of Boost Flyback converter and the Figures shown below 2(a) is Integrated Boost fly back converter (IBFC) but here the problem is the voltage across the switch is $\mathrm{V}_{\mathrm{sw}}=\mathrm{V}_{\mathrm{p}}+\mathrm{V}_{\mathrm{c} 1}$. Let us consider one example that $\mathrm{V}_{\mathrm{s}}=25 \mathrm{~V}, \mathrm{D}=0.5 \mathrm{~V} \& \mathrm{~V}_{\mathrm{cl}}=50 \mathrm{~V}$ (boost operation) and $\mathrm{V}_{\mathrm{p}}=50 \mathrm{~V}$ then the switch voltage becomes $\mathrm{V}_{\mathrm{sw}}=\mathrm{V}_{\mathrm{p}}+\mathrm{V}_{\mathrm{c} 1}=100 \mathrm{v}$ and in transient period the voltage may goes to $10 \mathrm{kv}$ hence switch may go to damage. To overcome this problem IBSPFC is used.

In this IBSPFC shown in Figure 2(b) the voltage stress is reduced because $\mathrm{V}_{\mathrm{SW}}=\mathrm{V}_{\text {IN }}+\mathrm{V}_{\mathrm{LB}}$ Let us consider one example $\mathrm{V}_{\mathrm{IN}}=25 \mathrm{~V}, \quad \mathrm{D}=0.5 \& \mathrm{~V}_{\mathrm{sw}}=\mathrm{V}_{\mathrm{IN}}+\mathrm{V}_{\mathrm{LB}}=50 \mathrm{~V}, \quad$ only and the capacitors $\mathrm{CB} 1$ and $\mathrm{CB} 2$ will acts as snubber circuit as well as bulk capacitor energy storage. The reliability is also present in this circuit because if any one of these capacitors or if any one of the fly-back transformers will damage the other transformer will transfers the half of the power to the load. To improve the efficiency and power transfer QSC based dual input configuration is used shown in Figure 2(c). The main advantage is Soft switching is implemented for both primary and secondary MOSFETS.

\section{OPERATION OF IBSPFC}

The main circuit diagram of IBSPFC shows in Figure 3. The functioning modes in single switching cycle can be indicated in four intervals, shown in Figure 4 and the pulse waveforms and the corresponding current waveforms are shown in Figure 5 .

In mode $1[0<\mathrm{t}<\mathrm{t} 1$ : Figure 4(a)]: When the $\mathrm{SW}$ is in on state then the input current start flowing through + Vin $-\mathrm{LB}-$ SW - (-Vin). Therefore, inductor current starts increasing and no current flows through the remaining part of the circuit.

In mode $2[\mathrm{t} 1<\mathrm{t}<\mathrm{t} 2$ : Figure $4(\mathrm{~b})]$ when the switch is in off state, then the current flows through +VIN - LB - CB1 - D2 - 
CB2 - (-VIN) and the inductor LB discharges and capacitors $\mathrm{CB} 1$ and $\mathrm{CB} 2$ will charge through diode D2.

In mode 3 [ $\mathrm{t} 2<\mathrm{t}<\mathrm{t} 3$ : Figure $4(\mathrm{c})]$ the switch is again turned on and the supply current flows through +Vin- LB - SW - (Vin). And the small amount of current flows through $+\mathrm{CB} 1-$ SW - Lfp2 - D1 - (-CB1) and +CB2 - D3 - Lpf1 - SW - (CB2). Due to reverse polarity of dot convention of fly-back transformer diode D4gets forward biased and the current flows through the output capacitor $\mathrm{C} 0$ and load resistance $\mathrm{R}$.

In Mode $4[\mathrm{t} 3<\mathrm{t}<\mathrm{t} 4$ : Figure $4(\mathrm{~d})]$ the switch is again turned off the bulk capacitors $\mathrm{CB} 1$ and $\mathrm{CB} 2$ get charged through +VIN - LB - CB1 - D2 - CB2 - (-VIN) and +Lpf1- CB1- D2 D3 - (-Lpf1) and +Lfp2 - D1 - D2- CB2 - (-Lfp2). Due to reverse polarity of dot convention diode $\mathrm{D} 4$ gets reverse biased then the output capacitor $\mathrm{C} 0$ will discharges its energy to the load R.

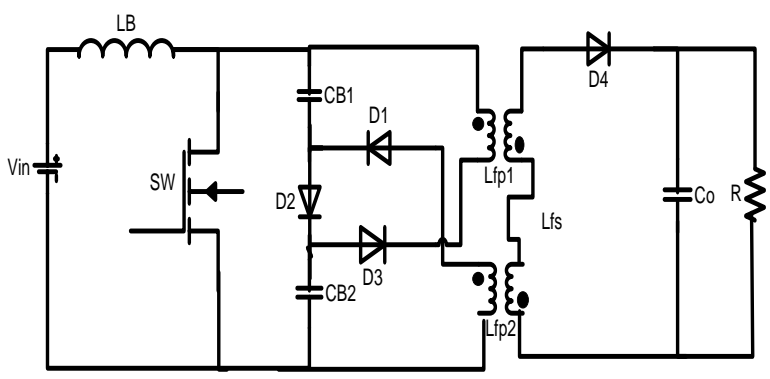

Figure 3. Integrated Boost Series Parallel Fly-back converter (IBSPFC)

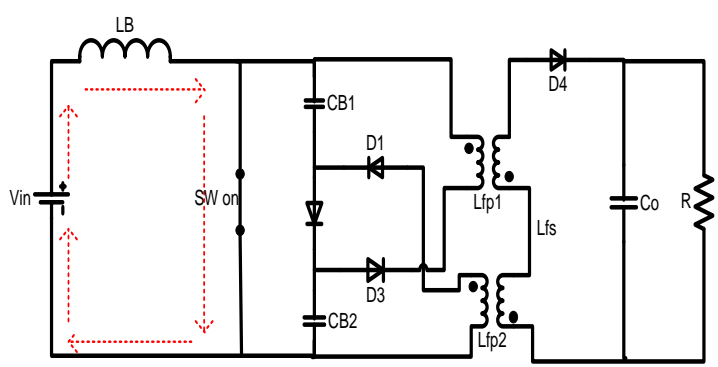

(a). Mode1 $(0<\mathrm{t}<\mathrm{t} 1)$

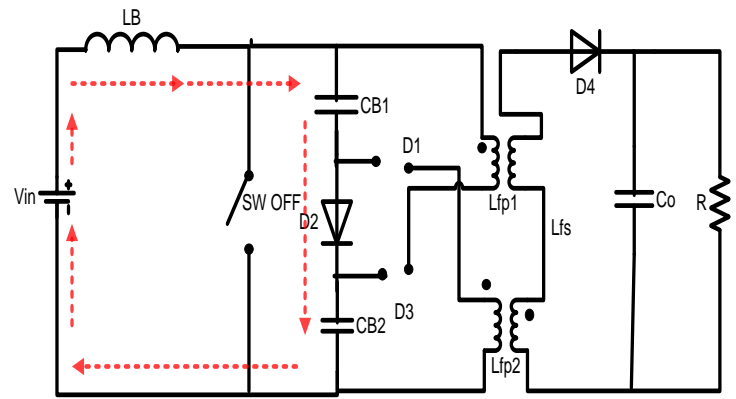

(b). Mode2 $(\mathrm{t} 1<\mathrm{t}<\mathrm{t} 2)$

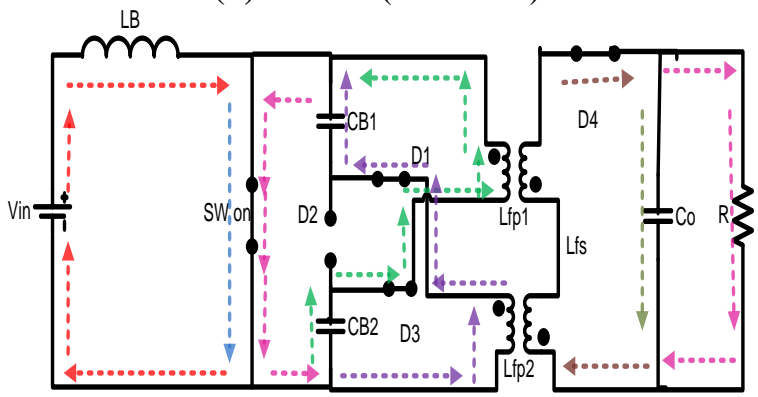

(c). Mode $3(\mathrm{t} 2<\mathrm{t}<\mathrm{t} 3)$

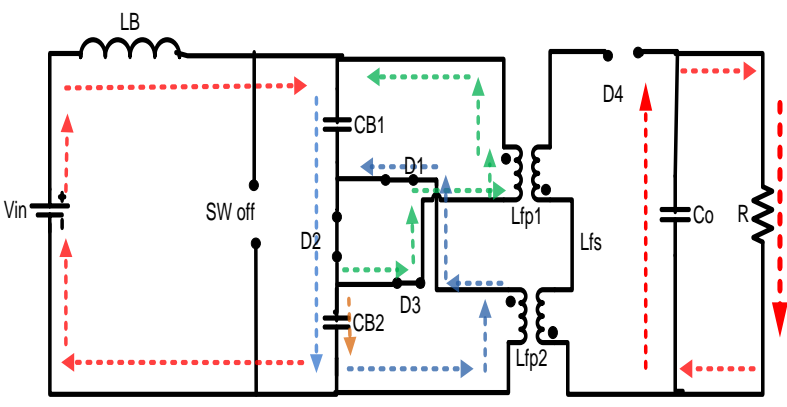

(d). Mode4 $(\mathrm{t} 3<\mathrm{t}<\mathrm{t} 4)$

Figure 4. Functioning modes of IBSPFC

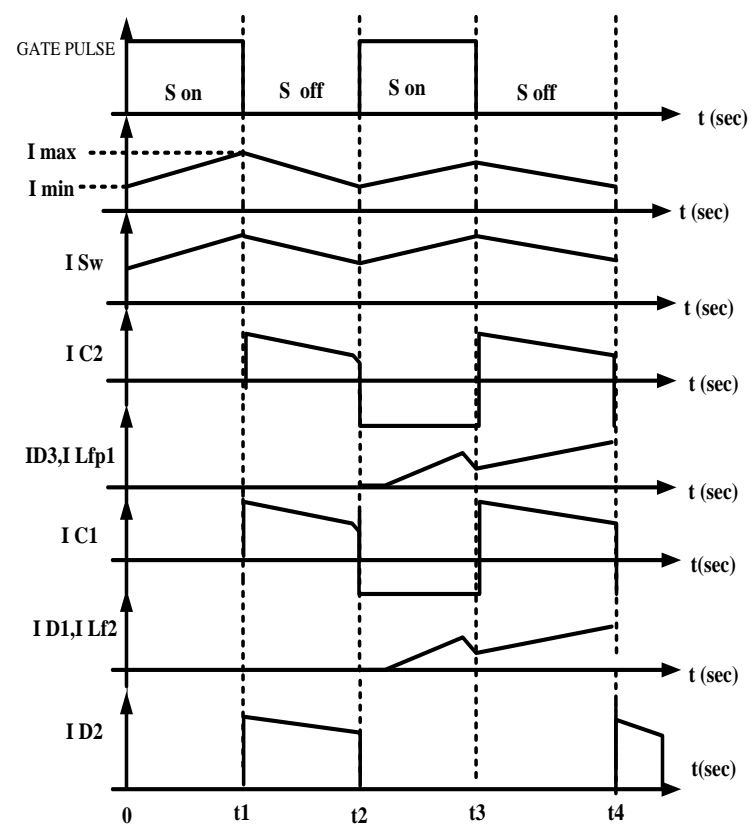

Figure 5. Current waveforms

\section{MATHEMATICAL ANALYSIS}

Input voltage $\mathrm{V}_{\mathrm{S}}=24 \mathrm{~V}$

Output Voltage $\mathrm{V}_{0}=48 \mathrm{~V}$

Output Current $\mathrm{I}_{0}=1.2 \mathrm{~A}$

Output Power $\mathrm{P}_{0}=48 \times 1.2=58 \mathrm{~W}$

$\mathrm{R}=40 \Omega$

For the step changer $\mathrm{R}=65 \Omega$

$$
\begin{gathered}
V_{0}=\frac{V_{S}}{(1-D)} \\
\therefore D=0.5 \\
I_{S}=\frac{I_{0}}{(1-D)} \\
=2.4
\end{gathered}
$$

But practically

$\mathrm{I}_{\mathrm{S}}=3.4 \mathrm{~A}$ is Obtained

$$
\eta=\frac{\text { OUTPUT }}{I N P U T}=\frac{58}{(24 * 3.4)}=68.2 \%
$$

To improve the efficiency \& More Reliability QSC Based IBSPFC is used. 


\section{EXPERIMENTAL RESULTS}

Experimental results are shows Figure 6(a). Home based kit, Figure 6(b): Output voltage and current (48 v n $1.2 \mathrm{amp}$ ), Figure 6(c): Capacitor Voltage (24 volts), Figure 6(d): Primary voltage and Current (24 volts n 2 amp), Figure 6(e): Secondary Voltage (48v only due to symmetrical), Figure 6(f): Gate pulse and inductor current (3.15Amp) and Figure 6(g): Switch voltage.

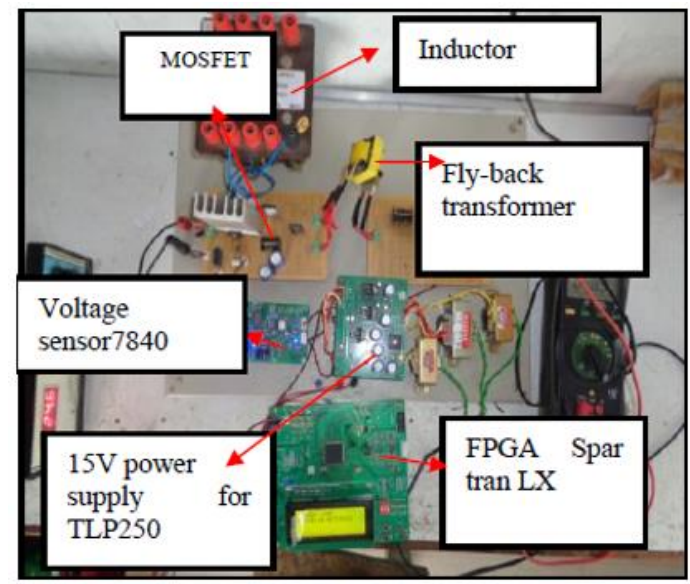

(a). Experimental set up of IBSPFC

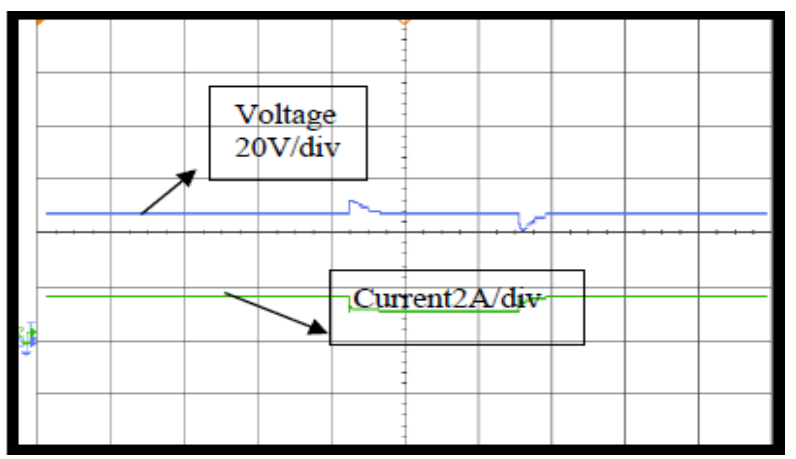

(b). Output voltage and current (48 V n $1.2 \mathrm{~A})$

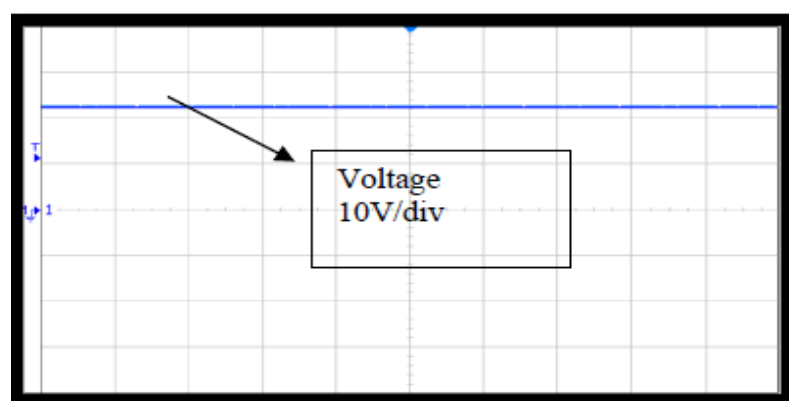

(c). Capacitor Voltage (24 V)

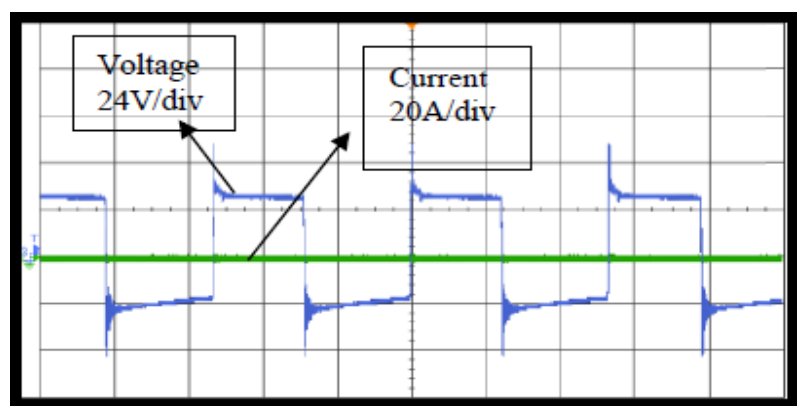

(d). Primary voltage and Current (24 V n 2 A)

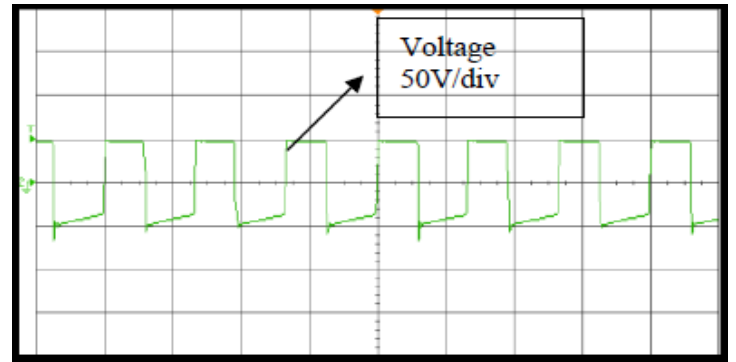

(e). Secondary Voltage (48V only due to symmetrical)

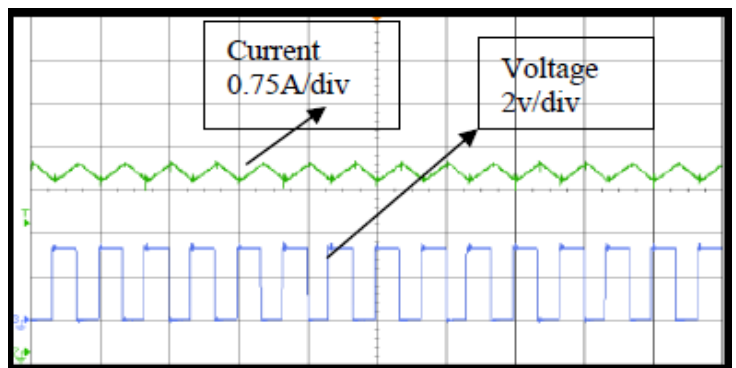

(f). Gate pulse and inductor current (3.15A)

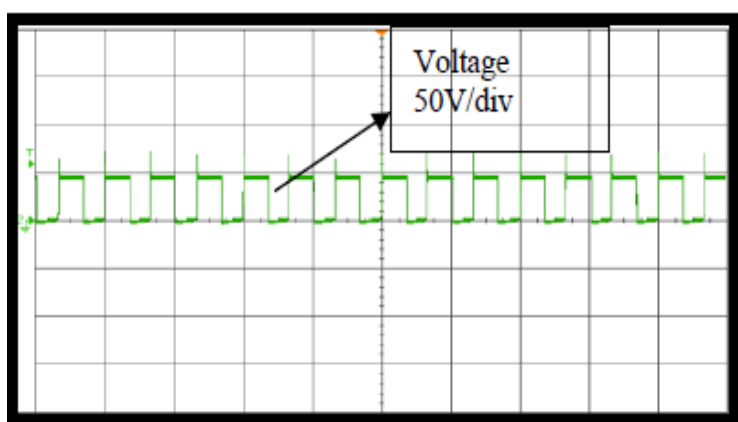

(g). Switch voltage

Figure 6. Output DC-DC closed loop waveforms

\section{WORKING METHODS OF QSC BASED IBSPFC}

Figure 7 shows the circuit diagram of QSC based IBSPFC. The working methods in particular switching cycle can be indicated in two-time intervals, shown in Figure 8 (a) \& 8(b) and the corresponding waveforms are shown in Figure 9(a) $\& 9$ (b).

In mode 1(M1) [0< $\mathrm{t}<\mathrm{t} 1$ : Figure 8(a)]: When the switches S1, S2, S3 are in ON condition. The current starts flowing through primary (Vin-L-S1) Therefore the boost inductor current starts increasing. Capacitor $\mathrm{C}^{\text {' }} \mathrm{C} 2$ ' will be discharging through (C1'-S1-D1) \& (C2'-D3-S1) and supplied to load [33]. On secondary side $\mathrm{C} 1, \mathrm{C} 3$ will be charging and $\mathrm{C} 2$ will be discharging though (C2-S2-Vbatt-C3-S3-C2).

In mode 2(M2) [t1<t $<\mathrm{t} 2$ : Figure 8(b)] the switch $\mathrm{S} 1, \mathrm{~S} 2$, S3 are switched off and S4 switched on. In this mode of operation, the current flows through the path of +Vin $-\mathrm{L}-\mathrm{Cl}$ 'D2-C2'-(-Vin). In this mode, the discharging of boost inductor takes place through the capacitors and diodeD2.and on secondary side capacitor $\mathrm{C} 1, \mathrm{C} 3$ are discharging and $\mathrm{C} 2$ is charging through-C2-Vbatt-S4- $(+\mathrm{C} 2)$. 


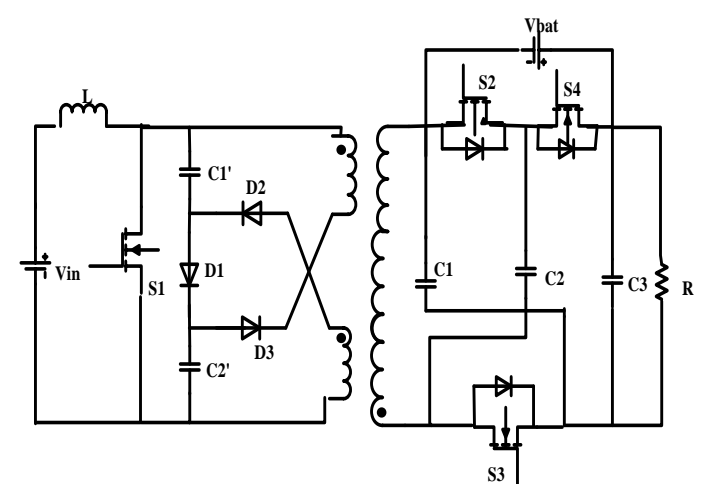

Figure 7. QSC based IBSPFC

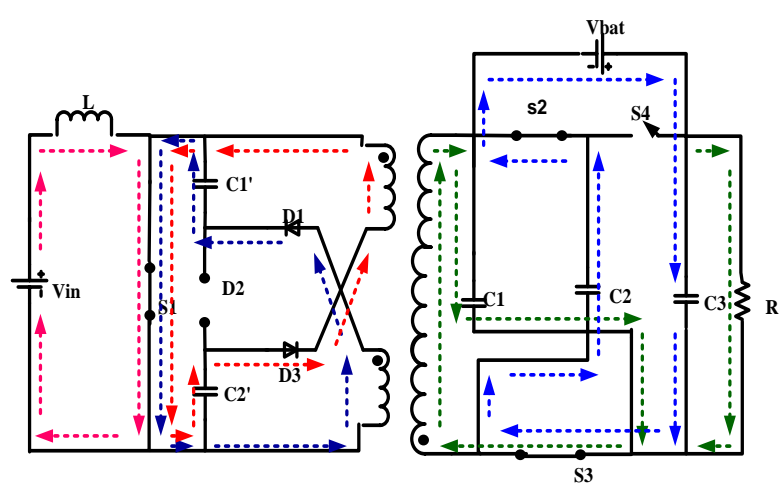

(a)

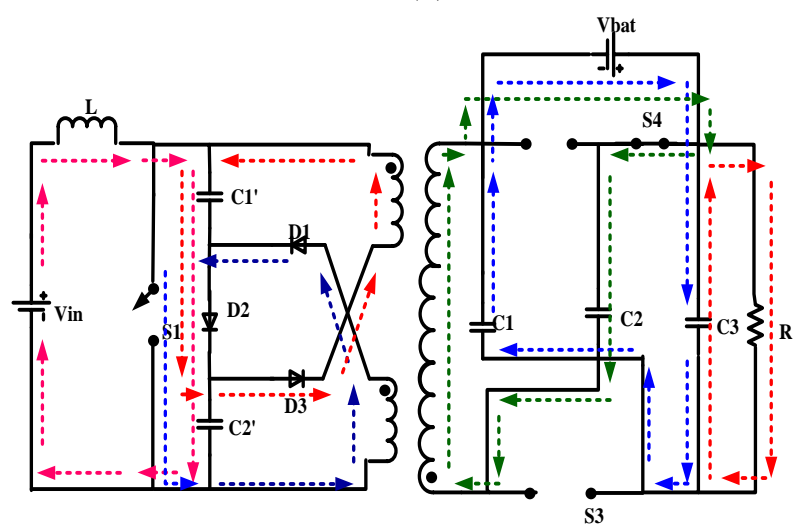

(b)

Figure 8. (a) Mode1 $(0<\mathrm{t}<\mathrm{t} 1)$; (b) Mode $2(\mathrm{t} 1<\mathrm{t}<\mathrm{t} 2)$

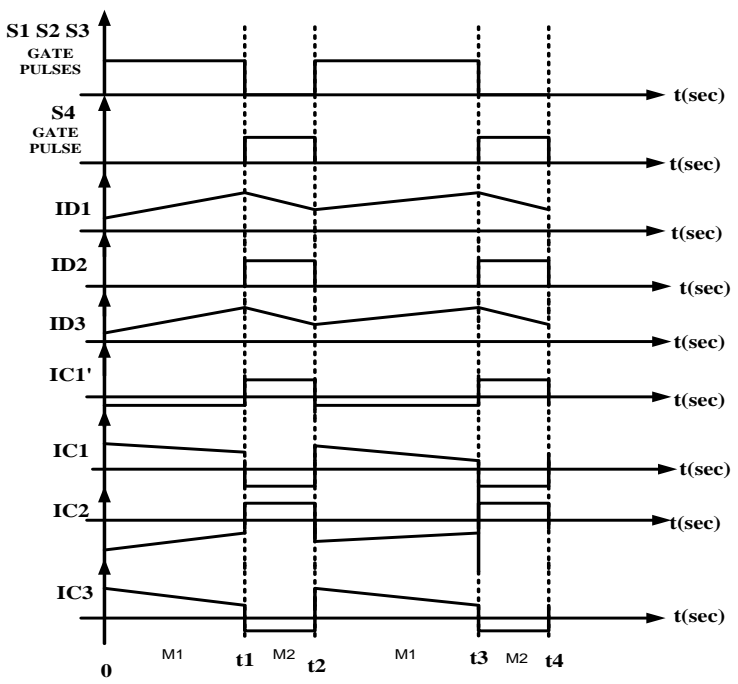

(a)

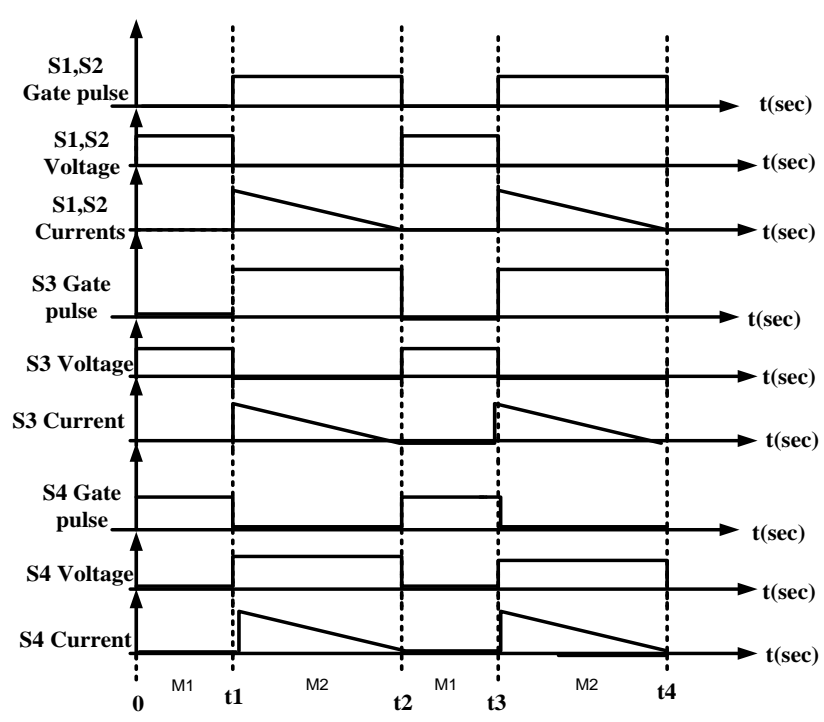

(b)

Figure 9. (a) Waveforms -1; (b) waveforms - 2

\section{MATHEMATICAL CALCULATIONS QSC BASED IBSPFC}

Mathematical calculations are obtained for the QSC based IBSPFC. Design specifications are $\mathrm{V}_{\text {in }}=25 \mathrm{~V}, \mathrm{~V}_{\mathrm{O}}=100 \mathrm{~V}$, $\mathrm{I}_{\mathrm{O}}=1 \mathrm{~A}, \mathrm{R}=100 \Omega, \mathrm{f}_{\mathrm{S}}=100 \mathrm{KHz}, \mathrm{P}_{\mathrm{O}}=100 \mathrm{~W}, \mathrm{~V}_{\mathrm{B}}=50 \mathrm{~V}$ and Battery $=50 \mathrm{~V}$.The design calculations for QSC based IBSPFC are presented below based on the assumption that primary side source and secondary side battery will share total load.

The Boost Convertor Output Voltage $\left(\mathrm{V}_{\mathrm{B}}\right)$, Input Current $\left(\mathrm{I}_{\mathrm{L}}\right)$, Boost Inductance $\left(\mathrm{L}_{\mathrm{B}}\right)$, Fly-back inductance $\left(\mathrm{L}_{\mathrm{F}}\right)$, Bulk Capacitors $\mathrm{C}_{\mathrm{B} 1}, \mathrm{C}_{\mathrm{B} 2}$ and output filter capacitor $(\mathrm{Co})$ are given as follows [34-37].

Boost Output Voltage:

$$
\begin{gathered}
V_{B}=\frac{V_{\text {in }}}{(1-D)} \\
\therefore D=0.5
\end{gathered}
$$

Boost Inductor current:

$$
\begin{aligned}
I_{S}= & \frac{I_{O b}}{(1-D)} \\
= & 1 \mathrm{~A}
\end{aligned}
$$

where, $\mathrm{I}_{\mathrm{ob}}$ is the Boost Converter Current delivery and Practically Is $=3 \mathrm{~A}$ is obtained for $100 \mathrm{~W}$. From the Boost Converter design Assume $\Delta i=0.05$.

Boost Inductance:

$$
\begin{gathered}
L_{B}=\frac{V_{B} D}{f_{S} \Delta i} \\
L_{B}=3.5 \mathrm{mh}
\end{gathered}
$$

Bulk Capacitance:

$$
C_{B}=\frac{D}{\left(2 * f_{S} * R\right)}
$$




$$
C_{B}=25 n f
$$

An approximation value of $100 \mu \mathrm{F}$ is chosen for practical case.

From the Fly-back Converter:

$$
\begin{gathered}
P=\frac{V_{B}{ }^{2} D^{2}}{\left(2 * L_{F} * f_{S}\right)} \\
L_{F}=53 \mu \mathrm{H}
\end{gathered}
$$

An approximation value of 40 to $50 \mu \mathrm{H}$ is chosen for practical case and the Secondary side Capacitors Values.

$$
C_{1}=C_{2}=C_{3}=100 \mu \mathrm{F}
$$

\section{EXPERIMENTAL RESULTS OF QSC BASED IBSPFC}

Figure 10 shows the experimental setup of QSC Based IBSPFC.

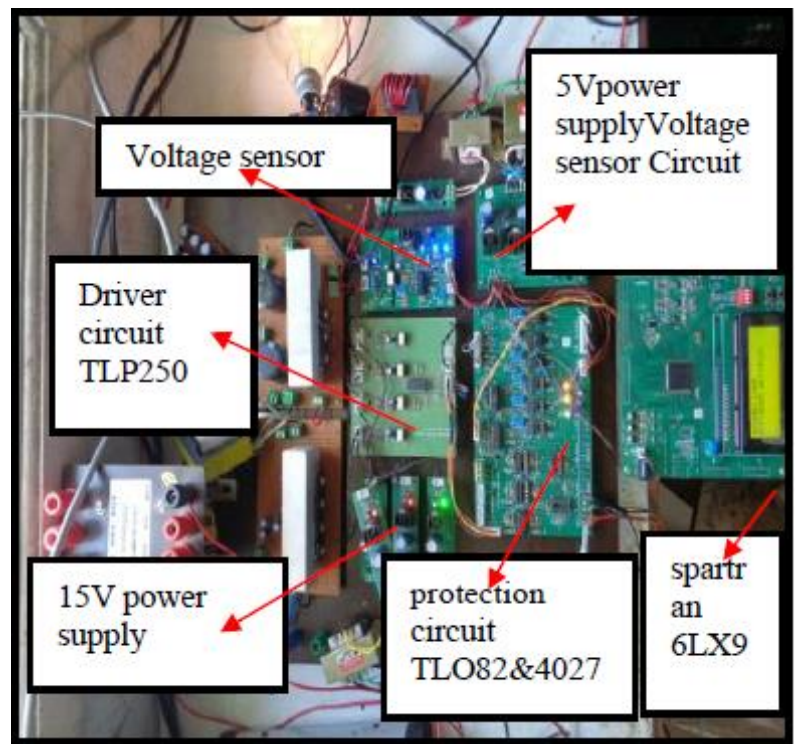

Figure 10. Experimental setup of IBSPFC with QSC

Figure 11 shows Zero voltage, Zero current Switching and Gate pulse of S2. Here the duty cycle is $50 \%$ and it is obtained from the FPGA SPARTRAN 6. From the FPGA the pulse magnitude is only $5 \mathrm{~V}$. But for the MOSFET minimum voltage requirement is $15 \mathrm{~V}$ and to achieve this TLP250 driver circuit is used. It can be seen that the voltage across the switch S2 will reaches zero once the gate pulse reaches the threshold voltage value. Also, the switch current magnitude is zero. Again, when the gate pulse will reach zero the voltage across the switch will increases and the current becomes almost zero. Therefore, Switch S2 realises ZVS ON, ZVS OFF, ZCS ON and ZCS OFF. The same will be applicable for switches S3 and S4 also. Figure 12 shows Zero Voltage, Zero Current Switching S3 and Gate pulse of S3, Figure 13 shows Zero voltage, Zero Current switching and Gate pulse of S4, Figure 14 shows Output Current 2A when the load is connected, Figure 15 shows Output Voltage $100 \mathrm{~V}$ for a small change in load the voltage variation is also shown in Figure 15, Figure 16 shows Input Source Current $3 \mathrm{~A}$ when the load is connected, Figure 17 shows Battery input Current 0.7A. Figure 18 represents efficiency curves of IBSPFC and QSC based IBSPFC. Table 1 shows the hardware details of DC-DC Converters.

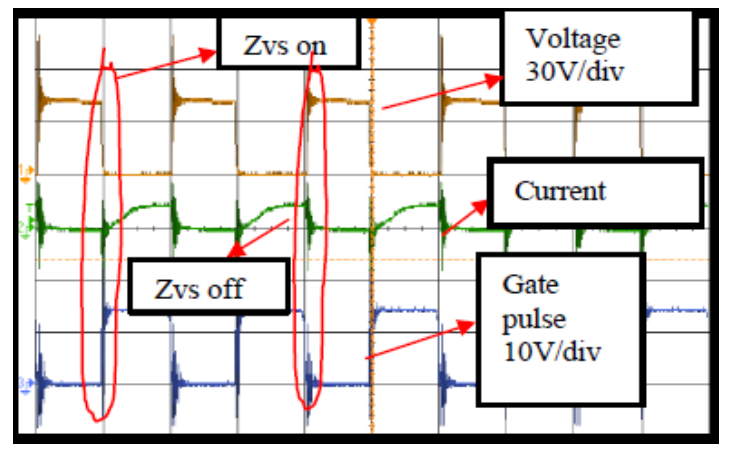

Figure 11. Zero voltage, Zero Current Switching S2

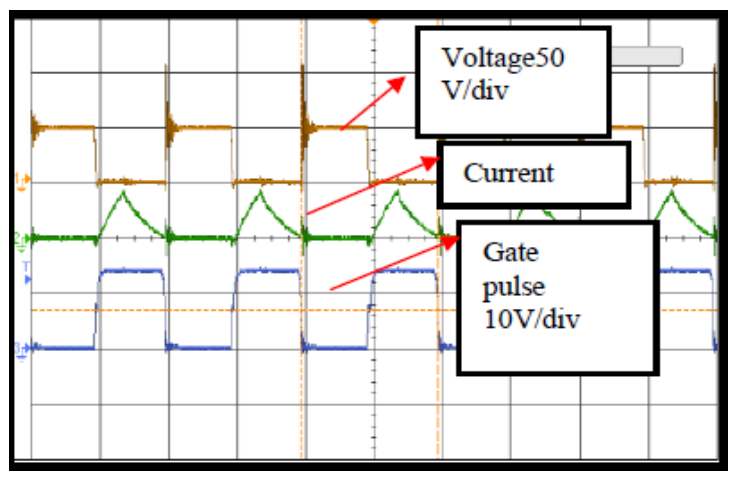

Figure 12. Zero Voltage, Zero Current Switching S3

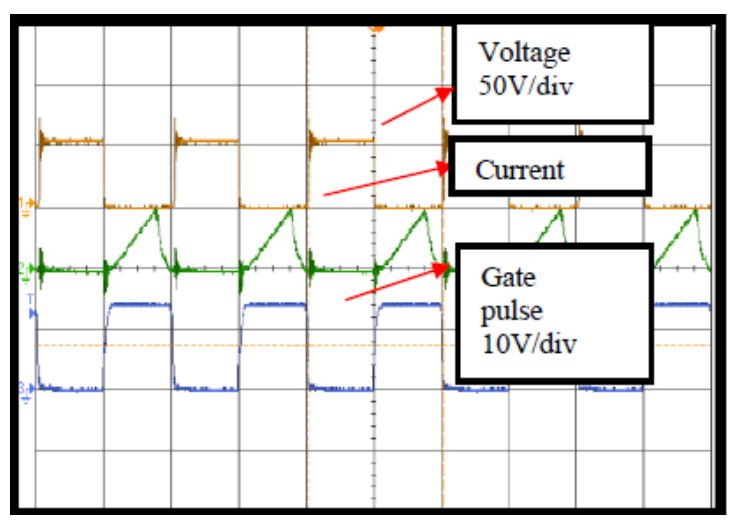

Figure 13. Zero voltage, Zero Current switching S4

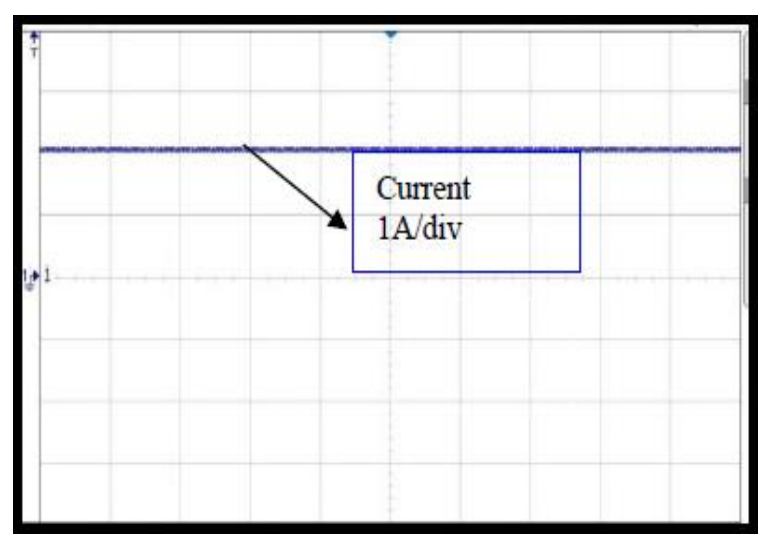

Figure 14. Output Current 2A 


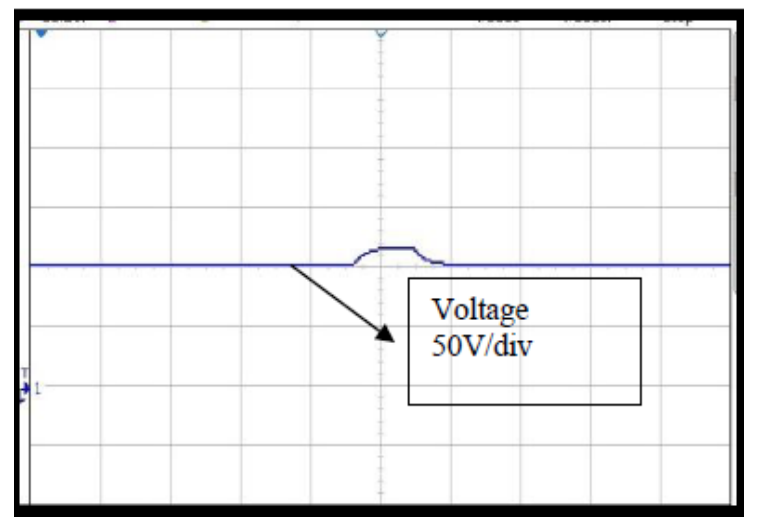

Figure 15. Output Voltage 100V

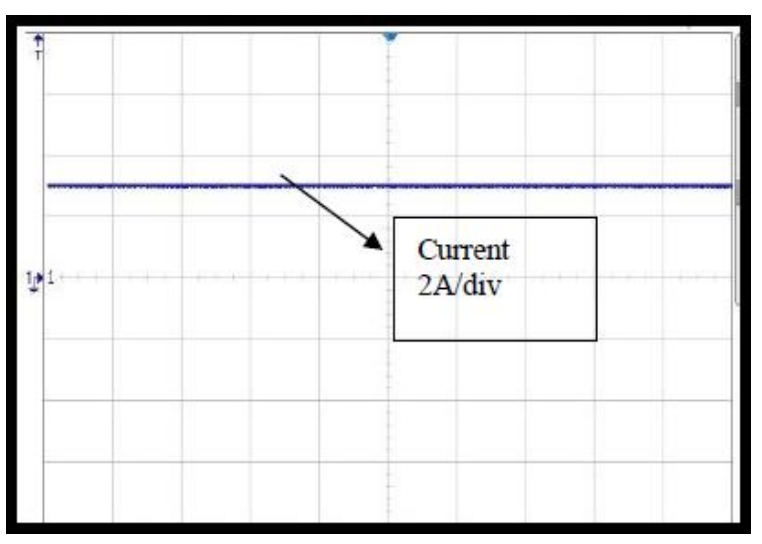

Figure 16. Input Source Current 3A

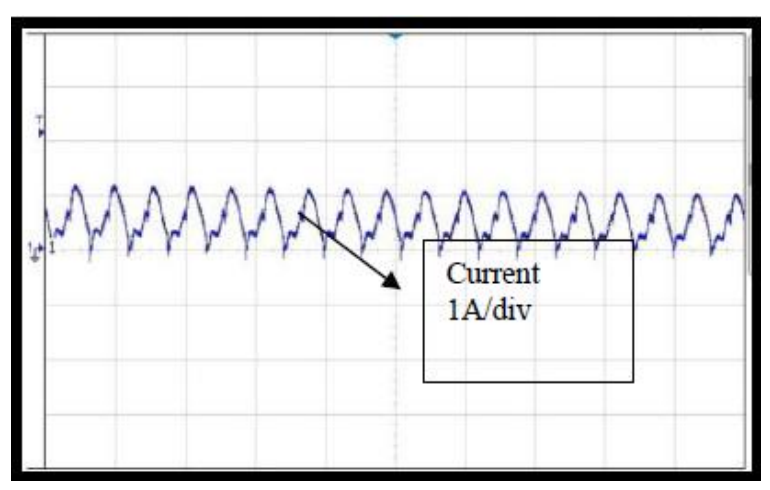

Figure 17. Battery input Current 0.7A

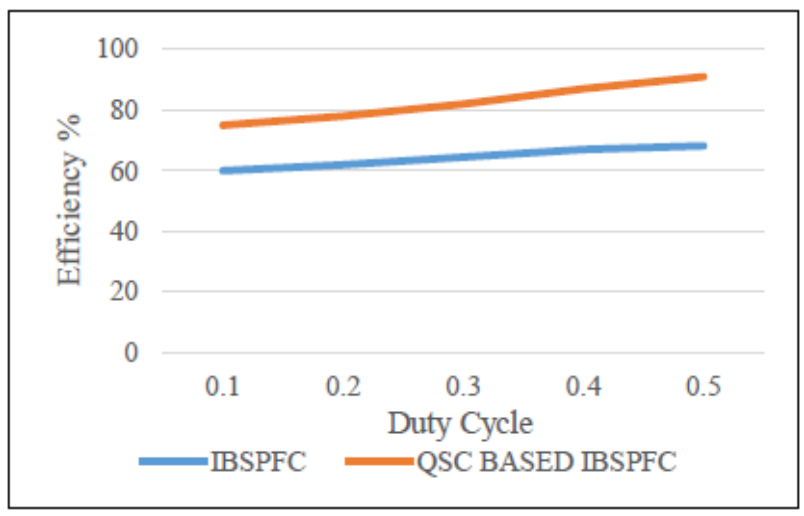

Figure 18. Efficiency curves of IBSPFC and QSC Based IBSPFC
Table 1. Hardware details

\begin{tabular}{ccc}
\hline Name & Number & Ratings \\
\hline Inductor & $100 \mathrm{Khz}, 1 \mathrm{~m}$ & $10 \mathrm{~A}$ \\
MOSFET & K2611 & Toshiba 900V, 9A \\
Diode & MUR3060 & $600 \mathrm{~V}, 30 \mathrm{~A}$ \\
Capacitors (Primary) & $63 \mathrm{~V}, 100 \mu \mathrm{F}$ & \\
Capacitors (Secondary) & $100 \mu \mathrm{F}, 100 \mathrm{~V}$ & \\
Transformer (ratio) & $1: 1$ & $50 \mathrm{~V} / 50 \mathrm{~V}$ \\
Transformer Inductance & & $45 \mu \mathrm{H}$ \\
Protection circuit & TL082 & \\
Spartan & $8 \mathrm{LX}$ & \\
\hline
\end{tabular}

Table 2. Comparison of IBSPFC \& QSC Based IBSPFC

\begin{tabular}{cc}
\hline IBSPFC & QSC Based IBSPFC \\
\hline Less Reliability when compare & High Reliability when compare \\
to QSC Based IBSPFC & to IBSPFC \\
Up to100W & Up to 200W \\
Efficiency is 68.2\% & Efficiency is 91\% \\
No Snubber Circuit is Required & No Snubber Circuit is Required \\
\hline
\end{tabular}

The Table 2 shows comparision of IBSPFC and Qsc Based IBSPFC. Here the IBSPFC reliablity is high when compare to conventional flyback converter, because of using mid-point transformer though if any one of the winding damages the power can be transferred with other winding of the transformer and also les swithing stress. But when compare to QSC Based IBSPFC the reliability is less because QSC based IBSPFC used to power supplies therefore if any power supply is not working other one will supply the power to the load.

\section{CONCLUSION}

This paper presents analysis and working methods of IBSPFC and QSC based IBSPFC. With this proposed connection of boost converter and fly back converter, the observations made are low switch voltage stress, tight voltage regulation with which the efficiency is improved. For the input voltage levels of $25 \mathrm{~V}, 50 \mathrm{~V}$ an output voltage of $100 \mathrm{~V}$ is obtained with the help of developed proto type which produces an output power of $100 \mathrm{w}$ at switching frequency of $100 \mathrm{KHz}$. The converter has the ability to operate at $200 \mathrm{w}$ also. The applications of this developed model are battery charging and series connection LED drives etc. With the combination of IBSPFC with QSC, the efficiency of the convertor increases that i.e. $91 \%$ and because of soft switching used in QSC helps to increase overall converter efficiency.

\section{REFERENCES}

[1] Omran, W.A., Kazerani, M., Salama, M.M.A. (2011). Investigation of methods for reduction of power fluctuations generated from large grid-connected photovoltaic systems. IEEE Trans. Energy Conversion, 26(1):

318-327. https://doi.org/10.1109/TEC.2010.2062515

[2] Solero, L., Lidozzi, A., Pomilio, J.A. (2005). Design of multiple-input power converter for hybrid vehicles. IEEE Trans. Power Electron, 20(5): 1007-1016. https://doi.org/10.1109/TPEL.2005.854020

[3] Khaliah, A., Cao, J., Lee, Y. (2009). A multiple-input dcdc converter topology. IEEE Trans. Power Electron, 24(3): 


\section{https://doi.org/10.1109/TPEL.2008.2009308}

[4] Rodriguez, F.D., Imes, W.G. (1996). Analysis and modeling of a two- input dc/dc converter with two controlled variables and four switched net-works. Proc. 31st Intersoc. Energy Convers. Eng. Conf., pp. 11-16. https://doi.org/10.1109/IECEC.1996.552892

[5] Chen, Y.M., Liu, Y.C., Lin, S.H. (2003). Double-input PWM dc/dc converter for high/low voltage sources. IEEE Transactions on Industrial Electronics, 53(5): 1538-1545. https://doi.org/10.1109/TIE.2006.882001

[6] Dobbs, B., Chapman, P. (2003). A multiple-input dc- dc converter topology. IEEE Power Electron Lett., 1(1): 69. https://doi.org/10.1109/LPEL.2003.813481

[7] Benavides, N.D., Chapman, P.L. (2005). Power budgeting of a multiple- input buck-boost converter. IEEE Trans. Power Electron., 20(6): 1303-1309. https://doi.org/ 10.1109/TPEL.2005.857531

[8] Dehghan, S.M., Mohamadian, M., Yazdian, A., Ashrafzadeh, F. (2010). A dual-input-dual-output Zsource inverter. IEEE Trans. Power Electron., 25(2): 360-368. https://doi.org/10.1109/TPEL.2005.857531

[9] Jiang, S., Peng, F.Z. (2012). Modular single-phase transZ-source inverter for multi-input renewable energy system. Proc. IEEE Applied Power Electronics Conference and Exposition (APEC), pp. 2107-2114. https://doi.org/10.1109/APEC.2012.6166112

[10] Kwasinski, A., Krein, P.T. (2007). Multiple-input dc-dc converters to enhance local availability in grids using distributed generation resources. In Proc. IEEE Applied Power Electronics Conference, pp. 1657-1663. https://doi.org/10.1109/APEX.2007.357741

[11] Chen, Y., Yu, X., Huang, A.Q. (2012). A new non isolated three-port DC- DC converter with high stepup/down ratio. In Proc. IEEE Energy Conversion Congress and Exposition (ECCE), pp. 1520-1526. https://doi.org/10.1109/ECCE.2012.6342633

[12] Zhu, H., Zhang, D., Zhang, B., Zhou, Z. (2015). A nonisolated three-port DC-DC converter and threedomain control method for PV- battery power systems. IEEE Trans. Industrial Electronics, 62(8): 4937-4947. https://doi.org/10.1109/TIE.2015.2393831

[13] Wu, H., Sun, K., Ding, S., Xing, Y. (2013). Topology derivation of non- isolated three-port dc-dc converters from DIC and DOC. IEEE Trans. Power Electron, 28(7): 3297-3307. https://doi.org/10.1109/TPEL.2012.2221746

[14] Liu, Y.C., Chen, Y.M. (2009). A systematic approach to synthesizing multi input dc-dc converters. IEEE Trans. Power Electronics, 24(1): 116-127. https://doi.org/10.1109/TPEL.2008.2009170

[15] Yu, W., Lai, J., Qian, H., Hutchens, C. (2011). Highefficiency MOSFET inverter with H6-type configure ration for photovoltaic non isolated AC- module applications. IEEE Trans. Power Electronics, 26(4): 1253-1260. https://doi.org/10.1109/TPEL.2010.2071402

[16] Shen, C., Tsai, C., Wu, Y., Chen, C. (2009). A modifiedforward multi- input power converter for solar energy and wind power generation. International Conference on Power Electronics and Drive Systems, pp. 631-636. https://doi.org/ 10.1109/PEDS.2009.5385865

[17] Chiu, H., Huang, H., Lin, L., Tseng, M. (2005). A multiple-input DC/DC converter for renewable energy systems. IEEE International Conference on Industrial Technology, pp. https://doi.org/10.1109/ICIT.2005.1600837
[18] Chen, Y., Liu, Y., Wu, F. (2002). Multi-input DC/DC converter based on the multi winding transformer for renewable energy applications. IEEE Trans. Industry Applications, 38(4): 1096-1104. https://doi.org/10.1109/TIA.2002.800776

[19] Yang, D., Ruan, X., Li, Y., Liu, F. (2009). Multiple-input full bridge $\mathrm{dc} / \mathrm{dc}$ converter. In Proc. IEEE Energy Conversion Congress and Exposition, pp. 2881-2888. https://doi.org/10.1109/ECCE.2009.5316485

[20] Kobayashi, K., Matsuo, H., Sekine, Y. (2006). Novel solar-cell power supply system using a multiple-input $\mathrm{dc}-\mathrm{dc}$ converter. IEEE Trans. Industrial Electronics, 53(1): 281-286. https://doi.org/10.1109/TIE.2005.862250

[21] Phattanasak, M., Gavagsaz-Ghoachani, R., Martin, J., Nahid- Mobarakeh, B., Pierfederici, S., Davat, B. (2015). Control of a hybrid energy source comprising a fuel cell and two storage devices using isolated three-port bidirectional DC-DC converters. IEEE Trans. Industry Applications, 51(1): 491-497. https://doi.org/10.1109/TIA.2014.2336975

[22] Ajami, A., Shayan, P. (2015). Soft switching method for multiport DC/DC converters applicable in grid connected clean energy sources. IET Power Electronics, 8(7): 12461254. https://doi.org/10.1049/iet-pel.2014.0592

[23] Li, Y., Ruan, X., Yang, D., Liu, F., Tse, C.K. (2010). Synthesis of multiple input dc/dc converters. IEEE Trans. Power Electronics, 25(9): 2372-2385. https://doi.org/10.1109/TPEL.2010.2047273

[24] Hu, Y., Xiao, W., Cao, W., Ji, B., Morrow, D. (2015). Three-port DC-DC converter for stand-alone photovoltaic systems. IEEE Trans. Power Electronics, 30(6): https://doi.org/10.1109/ECCE.2012.6342633

[25] Yu, S., Kwasinski, A. (2012). Multiple-input softswitching converters in renewable energy applications. In Proc. IEEE Energy Conversion Congress and Exposition (ECCE), pp. 1711-1718. https://doi.org/10.1109/ECCE.2012.6342606

[26] Ding, Z., Yang, C., Zhang, Z., Wang, C., Xie, S. (2014). A novel soft- switching multiport bidirectional DC-DC converter for hybrid energy storage system. IEEE Trans. Power Electronics, 29(4): 1595-1609. https://doi.org/10.1109/TPEL.2013.2264596

[27] Zeng, J., Qiao, W., Qu, L. (2015). An isolated three-port bidirectional DC-DC converter for photovoltaic systems with energy storage. IEEE Trans. Industry Applications, 51(4): 3493-3503. https://doi.org/10.1109/TIA.2015.2399613

[28] Wang, Q., Zhang, J., Ruan, X., Jin, K. (2011). Isolated single primary winding multiple-input converters. IEEE Trans. Power Electronics, 26(12): 3435-3442. https://doi.org/10.1109/TPEL.2010.2103958

[29] Su, G.J., Peng, F.Z. (2005). A low cost, triple-voltage bus $\mathrm{dc} / \mathrm{dc}$ converter for automotive applications. In Proc. 20th Annu. IEEE trans. power electronic. Conf. Expo, pp. 1015-1021. https://doi.org/10.1109/APEC.2005.1453116

[30] Su G., Tang, L. (2009). A Reduced-part, triple-voltage DC-DC converter for EV/HEV power management. IEEE Trans. Power Electron, 24(10): 2406-2410. https://doi.org/10.1109/APEC.2005.1453116

[31] Wu, H., Zhang, J., Xing, Y. (2015). A family of multiport buck-boost converter based on DC-link-inductors 
(DLIS). IEEE Trans. Power Electron, 30(2): 735-746. https://doi.org/ 10.1109/TPEL.2014.2307883

[32] Zhu, H., Zhang, D., Athab, H., Wu, B., Gu, Y. (2015). $\mathrm{PV}$ isolated three-port converter and energy -balancing control method for PV-battery power supply applications. IEEE Trans. Ind. Electron, 62(6): 3595-3606. https://doi.org/10.1109/TIE.2014.2378752

[33] Sivaprasad, A., Deepa, K., Mathew, K. (2012). Half bridge converter for battery charging application. Int. J. Eng. Res. Appl, 2(4): 994-999.

[34] Alonso, M.J., Costa, M.A.D., Ordiz, C. (2008). Integrated buck-fly-back converter as a high-powerfactor off-line power supply. IEEE Transactions on industrial Electronics, 55(3): 1090-1100. https://doi.org/10.1109/TIE.2007.908530
[35] Rodriguez, F.D., Imes, W.G. (1996). Analysis and modeling of atwo input dc/dcconverter with two controlled variables and four switched net-works. in Proc. 31st Intersoc. Energy Convers. Eng. Conf., pp. 11-16. https://doi.org/10.1109/IECEC.1996.552892

[36] Dehghan, S.M., Mohamadian, M., Yazdian, A., Ashrafzadeh, F. (2010). A dual input-dual output zsource inverter. IEEE Trans. Power Electron, 25(2): 360368. https://doi.org/10.1109/TPEL.2009.2028345

[37] Suresh, A., Rashmi, M.R., Madusuthanan, V., Kumar, V.P. (2016). Closed loop control of bi-directional soft switched quasi $\mathrm{Z}$-source dc-dc converter. Scientific Research, 7(5): 574-584. https://doi.org/10.4236/cs.2016.75049 